\title{
Optimization of UV-Electroproxone procedure for treatment of landfill leachate: the study of energy consumption
}

\author{
Majid Kermani $^{1,2} \cdot$ Abbas Shahsavani $^{3,4} \cdot$ Pegah Ghaderi $^{5} \cdot$ Pooria Kasaee $^{6} \cdot$ Jamal Mehralipour $^{7,8}$
}

Received: 22 January 2020 / Accepted: 5 November 2020 / Published online: 22 January 2021

(C) The Author(s) 2021

\begin{abstract}
With increased population, treatment of solid waste landfill and its leachate is of major concern. Municipal landfill leachate shows variable, heterogeneous and incontrollable characteristics and contains wide range highly concentrated organic and inorganic compounds, in which hampers the application of a solo method in its treatment. Among different approaches, biological treatment can be used, however it is not effective enough to elimination all refractory organics, containing fulvic-like and humic-like substance. In this experimental study, the UV Electroperoxone process as a hybrid procedure has been employed to treat landfill leachate. The effect of various parameters such as $\mathrm{pH}$, electrical current density, ozone concentration, and reaction time were optimized using central composite design (CCD). In the model fitting, the quadratic model with a P-Value less than 0.5 was suggested $\left(<0.0001\right.$ ). The $\mathrm{R}^{2}, \mathrm{R}^{2}$ adj, and $\mathrm{R}^{2}$ pre were determined equal to $0.98,0.96$, and 0.91 respectively. Based on the software prediction, the process can remove $83 \%$ of initial COD, in the optimum condition of $\mathrm{pH}=5.6$, ozone concentration of $29.1 \mathrm{mg} / \mathrm{l}$. min, the current density of $74.7 \mathrm{~mA} / \mathrm{cm}^{2}$, and process time of $98.6 \mathrm{~min}$. In the optimum condition, $55 / 33 \mathrm{mM} \mathrm{H}_{2} \mathrm{O}_{2}$ was generated through electrochemical mechanism. A combination of ozonation, photolysis and electrolysis mechanism in this hybrid process increases COD efficiency removal up 29 percent which is higher than the sum of separated mechanisms. Kinetic study also demonstrated that the UV-EPP process follows pseudo-first order kinetics $\left(\mathrm{R}^{2}=0.99\right)$. Based on our results, the UVEPP process can be informed as an operative technique for treatment of old landfills leachates.
\end{abstract}

Keywords Optimization $\cdot$ UV-Electroproxone process $\cdot$ landfill leachate $\cdot$ Design Expert software

Jamal Mehralipour

Mehralipour.J@IUMS.ac.ir; Jamalmehralipour@yahoo.com

1 Research Center for Environmental Health Technology, Iran University of Medical Sciences, Tehran, Iran

2 Department of Environmental Health Engineering, School of Public Health, University of Medical Sciences, Tehran, Iran

3 Environmental and Occupational Hazards Control Research Center, Shahid Beheshti University of Medical Sciences, Tehran, Iran

4 Department of Environmental Health Engineering, School of Public Health, Shahid Beheshti University of Medical Sciences,

Tehran, Iran

5 Master of Environment Engineering Water and Wastewater, West Tehran Branch Islamic Azad University, Tehran, Iran

6 Master of Civil Engineering, Azad University of Tehran West Branch, Tehran, Iran

7 Student Research Committee, Iran University of Medical Sciences, Tehran, Iran

8 Environmental Health Engineering, Iran University of Medical Sciences, Tehran, Iran

\section{Introduction}

In recent decades, a considerable increment of annual solid waste production (8-10\%) has been experienced all over the world [1]. The main drawback imposed on landfilling is leachate generation. The refractory organics, like fulvic-like and humic-like materials, linger in the leachate, especially old leachate. The release of this wastes can cause important environmental concerns due to production of more harmful and toxic compounds in leachate [2]. Therefore, advanced treatment is necessary to destroy these refractory organics and improve biodegradability before discharge [3, 4]. Ozonation has been increasingly used for treating the resistant organic compound $[5,6]$. In ozonation, organic contaminants can be oxidized by ozone molecules and/or hydroxyl radicals $\left(\mathrm{OH}^{\bullet}\right)$ produced from the decay of ozone molecules [7, 8]. Throughout ozonation, uncompleted degradation of refractory pollutant occurs. To overcome this dilemma, ozonation has been conservatively applied with other methods like ultraviolet irradiation $\left(\mathrm{UV} / \mathrm{O}_{3}\right)$ and $\mathrm{H}_{2} \mathrm{O}_{2}\left(\mathrm{H}_{2} \mathrm{O}_{2} / \mathrm{O}_{3}\right.$, i.e., peroxone 
process) as an advance oxidation process $\left(\mathrm{AOP}_{\mathrm{s}}\right)$ [9]. In the peroxone process, hydroxyl radicals were generated (Eqs. 1, 2) [10].

$\mathrm{H}_{2} \mathrm{O}_{2}+\mathrm{O}_{3} \rightarrow \mathrm{OH}^{\bullet}+\mathrm{O}_{2}^{\bullet}+\mathrm{O}_{2}$

$\mathrm{O}_{3}+\mathrm{H}_{2} \mathrm{O}+e-\rightarrow \mathrm{HO}^{\bullet}+\mathrm{O}_{-}{ }_{2}+\mathrm{OH}-$

Advance Oxidation Process (AOPs), which depend mainly on the formation of the free radicals to destroy organic materials, have revealed good prospective in the treatment of organic pollutants [1]. In hybrid AOPs (HAOPs), combination of two or more mechanisms are utilized for generation of oxidants such as $\mathrm{OH}^{*}$. The advantage of HAOPs is highperformance oxidation and mineralization of resistant organic compounds without the possibility of producing intermediates and secondary waste [2]. One common $\left(\mathrm{HAOP}_{\mathrm{s}}\right)$ is the electro-proxone process (EPP) [3]. In the EPP, the required ozone is produced through an ozone generator, while hydrogen peroxide is formed in the surface of cathode [3]. Further, the electrically produced $\mathrm{H}_{2} \mathrm{O}_{2}$ reacts with ozone and consequently, $\mathrm{OH}^{*}$ is formed (Eq. 1) [1]. With the purpose of accelerating the production of $\mathrm{OH}^{\circ}$, ultraviolet (UV) irradiation can be employed in (EPP) as the photoelectro-peroxone process (UV-EPP or Photo- EPP) [11]. According to Eqs. 3-5, Photolysis of ozone and $\mathrm{H}_{2} \mathrm{O}_{2}$ produces $\mathrm{OH}^{\bullet}[3,12]$. The benefits of utilizing UV-EPP method are its manageable system, controlled production of hydrogen peroxide without the need of adding excess amount, no sludge producing and its simple, environmentally friendly process $[1,5]$.

$\mathrm{H}_{2} \mathrm{O}_{2}+\mathrm{UV} \rightarrow 2 \mathrm{HO}^{\bullet}$

$\mathrm{O}_{3}+\mathrm{H}_{2} \mathrm{O}+\mathrm{UV} \rightarrow 2 \mathrm{HO}^{\bullet}+\mathrm{O}_{2}$

$\mathrm{O}_{3}+\mathrm{UV} \rightarrow \mathrm{O}+\mathrm{O}_{2}$

Response surface methodology (RSM) is the combination of mathematical and statistical methods to investigate the impact of different variables of one process [13-15]. Previous reports have been studied the applicability of different AOPs as per or post-treatment of leachate. for instance, Wang and et al. [16] used the $\mathrm{E}^{+}$-ozonation technique for concentrated leachate disposal. Ma and et al.[17] used catalytic microozonation through $\mathrm{Fe}_{3} \mathrm{O}_{4}$ nanoparticles @ cow-dung ash for advanced treatment of biologically pre-treated leachate. In this research, the effect of important operating factors on UV-EPP (i.e., $\mathrm{pH}$, current density, the concentration of initial ozone, and reaction time) were studied via central composite design (CCD). In addition, the consumed electrical energy, Kinetic of reactions and the synergist effect were investigated in optimum condition.

Finally, we applied novel AOPs to the treatment of leachate. This process is a hybrid process that photolysis, electrolysis, and simple ozonation mechanisms are used to direct and indirect oxidation of organic matter in leachate. The goal of UV-EPP was the generation of free oxidation radicals, and enhance the efficiency.

\section{Materials and methods}

\section{Landfill leachate characteristics}

The untreated landfill leachate was collected from the Hamadan sanitary landfill location placed in Hamadan province, west of Iran (34• 57'52 N and 48• 37’08 E) (Fig. 1). Landfill leachate was collected in $4 \mathrm{~L}$ glass vessels and kept in a refrigerator at $4-6{ }^{\circ} \mathrm{C}$. the main characteristics were measured according to the instructions given in the reference of water and wastewater examination [18]. Some of main characteristics of the landfill leachate have been presented in Table 1 . The satellite and real image of the leachate accumulation in the Hamadan landfill site have been shown in Fig. 1.

\section{Chemical and reagents}

Sulfuric acid $\left(\mathrm{H}_{2} \mathrm{SO}_{4} 96 \%\right)$ and sodium hydroxide $(\mathrm{NaOH}$ 98\%) were purchased from Merck Company, COD vials (high range $0-1500 \mathrm{mg} / \mathrm{l})$ were prepared from Laviband Company. The analysis was performed by spectrophotometer (DR6000 HACH Co.), Low pressure mercury lamp $(254 \mathrm{~nm}, 6 \mathrm{~W}$, Philips Morgian, USA (, Oxygen and Ozone generator (PORSA model, ARDA Co. France), $\mathrm{pH}$ meter $(\mathrm{HACH}$ Co.), DC source (5.00 A, 50 V, P405, ADAK Co.), Graphene electrodes $(20 \mathrm{~cm} \times 2 \mathrm{~cm}$, Etemad Gostar Iranian Co.), and impugner (1 liter, DURAN Co.).

\section{Experimental procedures}

UV-EPP pilot consists of a one-liter batch quartz cylinder covered by UPVC box (Fig. 2). The experiments were conducted at room temperature $(25 \pm 3)$. Two pairs of graphene electrodes as cathodes and anodes immersed in the middle of the reactor were used. The distance between the electrodes was $1.0 \mathrm{~cm}$. Ozone gas was constantly produced from a pure $\mathrm{O}_{2}$ feed gas (99.9\%) through an ozone generator and then diffuse into the aqueous by fine bubble diffuser. The ozone concentration in the gas $\left(\mathrm{O}_{2} / \mathrm{O}_{3}\right.$ mixture $)$ can be tuned via altering the power of ozone generator. The Direct electric current (DC) power supply was applied to employ electrical current in controlled conditions. For UV irradiation, a lowpressure UV-C lamp (254 nm, $16 \mathrm{~W}$ ) emission wavelength in the quartz tube was used such that the lamp was located axially inside the reactor. In this condition, UV intensity was $2.3 \mathrm{~mW} / \mathrm{cm}^{2}$ (corresponding to a photon fluency rate of 


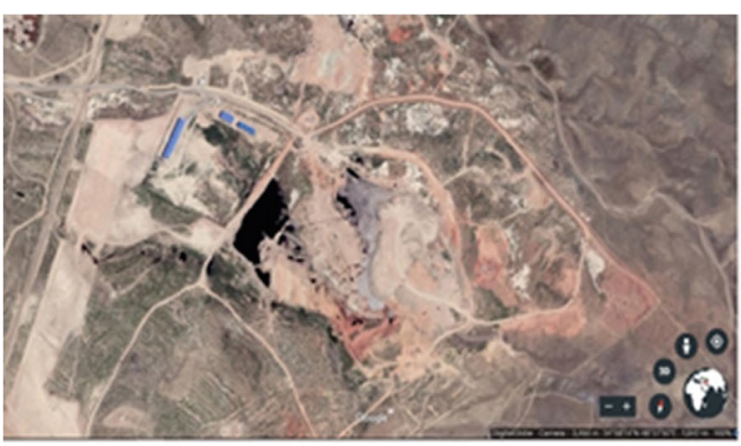

a

Fig. 1 a Satellite image, $\mathbf{b}$ the real image of the landfill site

$1.84 \times 105$ Einstein $\left.\mathrm{m}^{2} . \mathrm{s}^{-1}\right)$. The content of the reactor was mixed with a magnetic stirrer $(120 \mathrm{rpm})$. Each mechanism (electrolysis, UV-photolysis, ozonation) was carried out at the same conditions and their synergist effect was also investigated, separately. In each run, $1000 \mathrm{~mL}$ of leachate was entered into the reactor. The initial $\mathrm{pH}$ of the leachate was adjusted with $\mathrm{H}_{2} \mathrm{SO}_{4}$ and $\mathrm{NaOH}(0.1 \mathrm{~N})$. The initial and final concentrations of COD were measured according to the instructions given by the standard method [1]. The UV-EPP was initiated by concurrently employing a continuous current to electro-generate $\mathrm{H}_{2} \mathrm{O}_{2}$, UV irradiation, and sparging ozonecontaining oxygen gas over the reactor. After each step of the run, 5 minutes of nitrogen stripping was applied to eliminate the remaining ozone gas in the solutions. The efficiency of COD was calculated by the following equation (Eq. 6).

CODremoval\% $=\frac{C f-C 0}{C 0} \times 100$

Where $\mathrm{C}_{0}$ and $\mathrm{C}_{\mathrm{f}}$ refer to the COD concentrations in the sample of leachate before and after the reaction, respectively.

\section{Electrical energy consumption calculations}

In the optimum condition of UV-EPP, the specific energy requirements (SER) for COD elimination throughout the ozonation, electrolysis, photolysis, and UV-EPP are survey via (Eqs. (7-10)), separately. Ozone consumption $\left(\mathrm{CO}_{3}\right)$ in ozonation and UV-EPP was calculated according to Eq. (11). The normal energy needed for ozone formation was expected to be $10 \mathrm{kWh} \mathrm{kg}^{-1} \mathrm{O}_{3}$ [19].

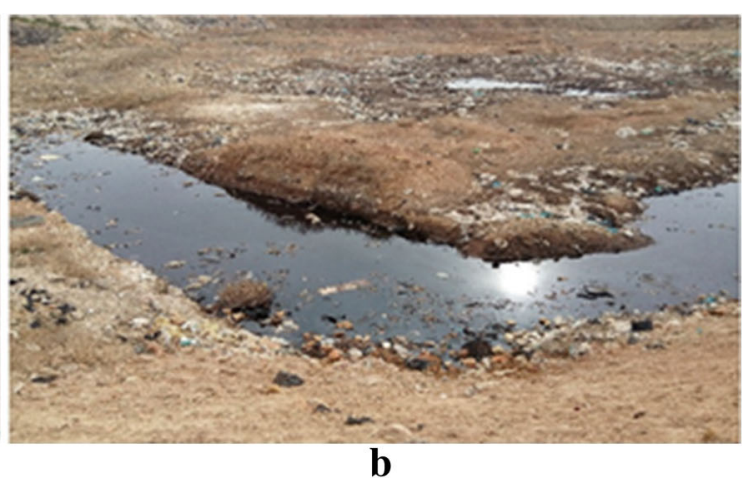

b

SERelectrolysis $(\mathrm{kWh} / \mathrm{gCODremoved})$

$$
=\frac{\mathrm{UIT}}{(\mathrm{COD} 0-\mathrm{CODt}) \mathrm{V}}
$$

SERphotolysis(kWh/gCODremoved)

$$
=\frac{\mathrm{Wt}}{(\mathrm{COD} 0-\mathrm{CODt}) \mathrm{V}}
$$

SERozonation (kWh/gCODremoved)

$$
=\frac{\mathrm{rCO} 3}{(\mathrm{COD} 0-\mathrm{CODt}) \mathrm{V}}
$$

SERUV - EPP $(\mathrm{kWh} / \mathrm{gCODremoved})$

$$
=\frac{\mathrm{UIT} \times \text { Uphotolysis } \times \mathrm{rCO} 3}{(\mathrm{COD} 0-\mathrm{COD}) \mathrm{V}}
$$

$\mathrm{CO} 3=\mathrm{Qg} ?([\mathrm{O} 3]$ inlet $-[\mathrm{O} 3]$ outlet $) \mathrm{dt}$

$\mathrm{SER}_{\text {Electrolysis }}, \mathrm{SER}_{\text {photolysis }} \mathrm{SER}_{\text {ozonation }}$, and $\mathrm{SER}_{\mathrm{UV}}$ -EPP are the specific energy requirement $(\mathrm{kWh} / \mathrm{g}$ COD removed) for electrolysis, photolysis, ozonation, and UVEPP, respectively; $U$ is the cell voltage $(\mathrm{V})$, I is the current (A), $\mathrm{T}$ is the reaction time (h), $\mathrm{r}$ is the energy requirement for ozone production $(10 \mathrm{kWh} / \mathrm{kg}$ ozone $)$, The minimal power of the UV lamp is $\mathrm{W}(10 \mathrm{~W})$ and corrected considering $60 \%$ lamp effectiveness consistent with the manufacturer's manual, $\mathrm{V}$ is the solution volume $(\mathrm{L}), \mathrm{CO}_{3}$ is the total ozone spent in ozonation and UV-EPP (g), Qg is the gas flow rate $(\mathrm{L} / \mathrm{min}),\left[\mathrm{O}_{3}\right]$ inlet and $\left[\mathrm{O}_{3}\right]$ outlet are the

\begin{tabular}{|c|c|c|c|c|c|c|c|c|}
\hline Constituent & $\mathrm{pH}$ & Ammonia nitrogen $(\mathrm{mg} / \mathrm{L})$ & $\mathrm{COD}(\mathrm{mg} / \mathrm{L})$ & $\mathrm{BOD}_{5}(\mathrm{mg} / \mathrm{L})$ & TOC $(\mathrm{mg} / \mathrm{L})$ & $\mathrm{BOD}_{5} / \mathrm{COD}$ ratios & $\mathrm{TP}(\mathrm{mg} / \mathrm{L})$ & TDS $(\mathrm{mg} / \mathrm{L})$ \\
\hline Value & $8 \pm 0.8$ & $2178 \pm 98$ & $9433 \pm 348$ & $1500.7 \pm 214.9$ & $6647 \pm 243.6$ & $0 / 15$ & 120 & 1200 \\
\hline
\end{tabular}
concentration of gas phase ozone $(\mathrm{mg} / \mathrm{L})$ at the reactor gas inlet and outlet, respectively [20].

Table 1 Main characteristics of the landfill leachate 
Fig. 2 Schematic view of UVEPP reactor

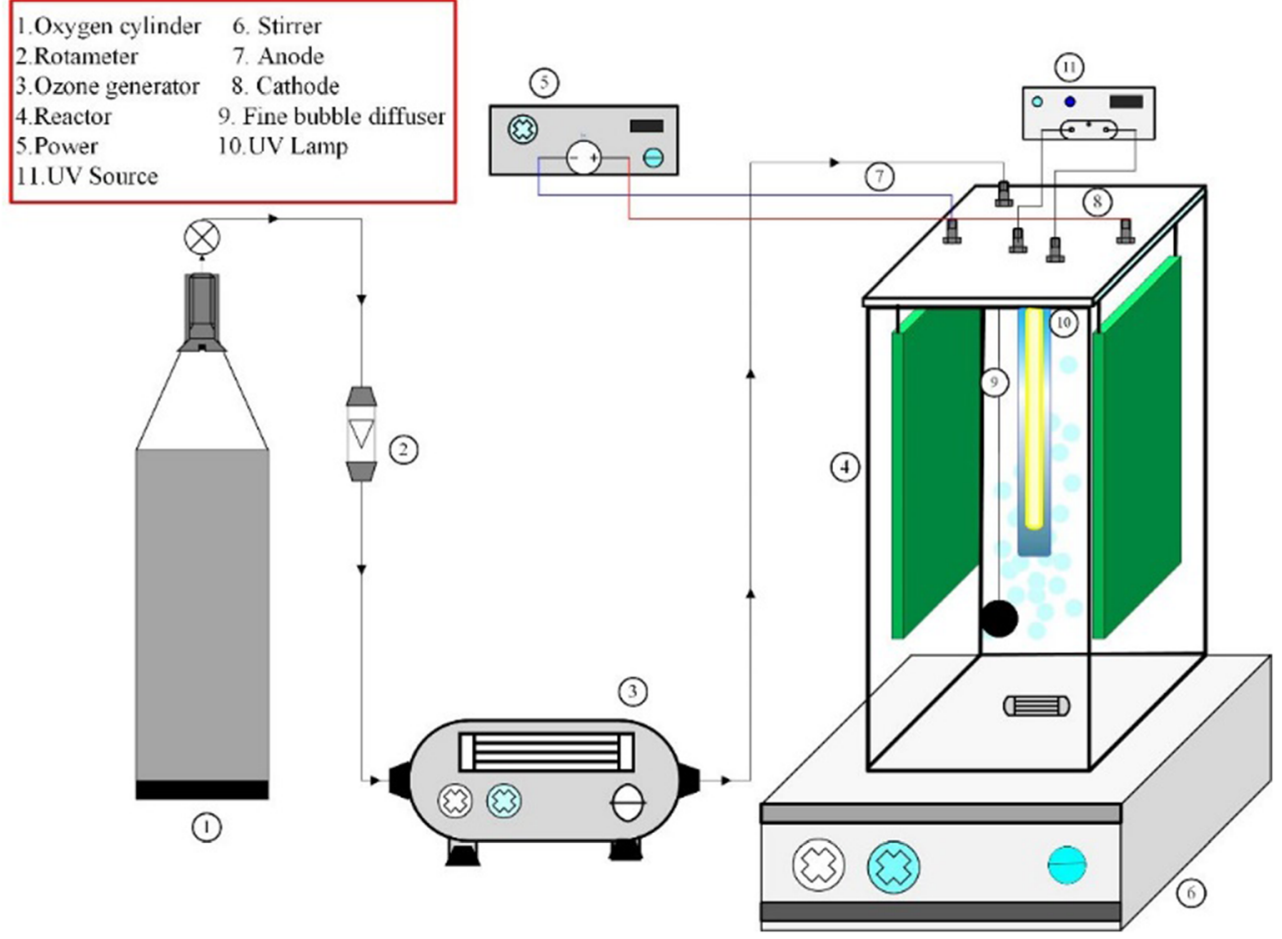

\section{Analytical methods}

The concentrations of ozone at the reactor's inlet and outlet were constantly checked by ozone analyzer (UV-300, Simson EP Hi-Tech Co.) in UV-EPP and ozonation process. The concentration of ozone in the aqueous was detected via the indigo technique [2]. The COD of leachate was measured via DR6000 spectrophotometer. $\mathrm{H}_{2} \mathrm{O}_{2}$ and $\mathrm{OH}^{\bullet}$ was calculated by the Terephthalate method [21].

\section{Experimental design}

The design of the experiment (DOE) typically is used to optimize the effective variables in the UV-EPP process to increase characteristics performance and decrease the experiments' error [22]. Here in, for the design, analysis, modeling, and predicate of the optimum condition in COD removal, the central composite design (CCD) via Design Expert Software (version 11) was used. The CCD is a mixture of mathematical and statistical procedure that was used to identify major variables and optimize the conditions. This method is an advanced technique of factorial design that provides precise models for curvature via considering the relations of factors. The level and range of factors were studied at five levels (Table 2). According to the CCD design, 30 experiments were planned (Table 4). The calculated responses involved the COD removal in different runs in UV-EPP. The CCD based results were investigated via ANOVA. The multi-degree coefficients of Eq. 12 were applied for determining the coefficients [23]. P- value with a $95 \%$ confidence level was employed to estimate the model functions effect.

$Y=\beta_{0}+\beta_{i} X_{i}+\beta_{j} X_{j}+\beta_{i i} X_{i}^{2}+\beta_{j j} X_{j}^{2}+\beta_{i j} X_{i} X_{j}$

$\mathrm{Y}, \mathrm{i}, \mathrm{j}, \mathrm{b}, \mathrm{X}$ are process response, linear coefficient, quadratic coefficient, regression coefficient and coded independent variables, respectively. $\beta$ is the correlation coefficient.

Then the single term impact and the interactions between the variables $(\mathrm{pH}$, ozone concentration, direct current and reaction time) on the UV-EPP process efficiency fitted and optimized via the quadratic polynomial model. This model simulates the process efficiency in the face of five linear variables, ten interacting factors, and five curved variables. The correlation coefficients $\left(\mathrm{R}^{2}, \mathrm{R}^{2}\right.$ adj. $\mathrm{R}^{2}$ predict) help to deduce the interactions of factors graphically and find the best performance in different conditions based on the surface of the three-dimensional response plots.

\section{Results and discussion}

\section{Design of experiments}

Initially, lack of fit teste (Table 3) for Linear, 2FI, quadratic and cubic models was done and this model was chosen for other analysis steps, due to the minor lack of fit and maximizing the attuned R-squared and the anticipated R-squared of the quadratic model. 
Table 2 Summary of design of UV-EPP based on CCD

\begin{tabular}{|c|c|c|c|c|c|c|c|c|}
\hline symbol & name & unit & $\begin{array}{l}\text { Min } \\
\text { level }\end{array}$ & $\begin{array}{l}\text { Max } \\
\text { level }\end{array}$ & $\begin{array}{l}\text { Low } \\
\text { level }\end{array}$ & $\begin{array}{l}\text { High } \\
\text { level }\end{array}$ & mean & Sd. \\
\hline A & $\mathrm{pH}$ & - & 2 & 10 & 4 & 8 & 6 & 1.789 \\
\hline B & $\mathrm{O}_{3}$ concentration & $\mathrm{mg} / \mathrm{l} . \mathrm{min}$ & 10 & 50 & 20 & 40 & 30 & 8.944 \\
\hline $\mathrm{C}$ & $\begin{array}{l}\text { Direct } \\
\quad \text { Current(DC) }\end{array}$ & $\mathrm{mA} / \mathrm{cm}^{2}$ & 18.75 & 93.75 & 56.25 & 75 & $65 / 25$ & 16.771 \\
\hline $\mathrm{D}$ & $\begin{array}{l}\text { Reaction } \\
\text { Time(RT) }\end{array}$ & $\min$ & 25 & 125 & 50 & 100 & 75 & 22.361 \\
\hline
\end{tabular}

The statistical model was used to find the optimal approximation of the system response. In the CCD, the experiments were planned in a random activity to minimize the effect of uncontrolled variables and errors. As presented (Tables 2 and 4), four independent variables ( $\mathrm{pH}$, ozone concentration, direct current, and reaction time), were selected in five levels as coded value $(-a, 1,0,+1,+a)$ and the responses of all observed 30 experiments was recovered and presented. Based on Table 4, the minimum and maximum efficiency of UV-EPP in the removal of COD was 63 and 79 percent, respectively. Analysis of variance was also performed to find the most significant variables effect and the interactions between them. The results were analyzed by ANOVA at $95 \%$ confidence level to fit the experimental results (Table 5). The P-Value and F-Value in the ANOVA were used to determine the role of each variable. The low P-Value (less than 0.05), indicated the significance of the selected model. In this model, P-Value above 0.05 , which reduced the statistical effect of significant variables, were removed and statistically significant related variables and interactions were included. Also, the lack of fit P-value confirms the significance and usability of the model.

The P-Value is less than 0.05 for the variables and their interactions, which means their statistical influence on the process. Based on the analyzed results, F-Value and P-value models were determined $(<0.0001)$ and 55.13, respectively. The lack of fitted P-value(0.4258) was more than 0.05 , so, indicating the considerably fitted model. The fitting regression model was also used to determine the effect of variables (Eq. 13).

Efficiency $(\%)=29.7+(0.5 \times \mathrm{pH})+(1.0 \times$ Ozone $)+(0.4 \times$ Current $(+(0.2 \times$ Time $)+(0.006 \times \mathrm{pH} \times$ Ozone $)+(0.001 \times$ Ozone $\times$ Current $)-(0.005 \times$ Ozone $\times$ Time $)+(0.002 \times$ Current $\times$ Time $)+(0.1 \times \mathrm{pH} 2)-(0.01 \times$ Ozone 2$)-(0.003 \times$ Current2)-(0.0008 $\times$ time2 ) [13].

$\mathrm{R}^{2}, \mathrm{R}^{2}$ Adj and $\mathrm{R}^{2}$ predict $(0.98,0.96$ and 0.91 , respectively) indicated the great relationship between experimental and predicted values.

\section{Effect of parameters}

Here in, response surface plots are presented to determine the single-terms and effect of interactions between variables in the removal of COD in UV-EEP. The three-dimension surface response provides important information about the interactions between the variables (Fig. 3).

Figure 3 demonstrates the variation of the COD removal efficiency as a function of the initial $\mathrm{pH}$ and ozone concentration, while the other variables were considered constant in the central point values $(\mathrm{DC}=65 / 25 \mathrm{~mA} / \mathrm{cm} 2, \mathrm{RT}=75 \mathrm{~min})$. The efficiency of UV-EPP was increased with increasing ozone gas concentration up to a certain point (middle concentration) and then the efficiency was decreased. The COD removal efficiency was decreased by increasing the $\mathrm{pH}$ which is an effective parameter on the chemical processes, especially AOPs. This parameter as a, directly and indirectly, influence on the processes. In AOPs, changing the $\mathrm{pH}$ value, affect the
Table 3 Lack of fit teste for CCD analysis

\begin{tabular}{lllllllll}
\hline Source & $\begin{array}{l}\text { Sum of } \\
\text { squared }\end{array}$ & $\begin{array}{l}\text { Degree of } \\
\text { freedom }\end{array}$ & $\begin{array}{l}\text { Mean } \\
\text { squares }\end{array}$ & $\begin{array}{l}\text { F- } \\
\text { value }\end{array}$ & $\begin{array}{l}p \text {-value } \\
\text { Prob }>\text { F }\end{array}$ & $\begin{array}{l}\text { F- } \\
\text { value } \\
\text { Lack of fit }\end{array}$ & $\begin{array}{l}p \text {-value } \\
\text { Prob }>\text { F }\end{array}$ & \\
\hline Linear & 352.5 & 4 & 88.13 & 13.14 & $<0.0001$ & 14.54 & 0.0038 & \\
2FI & 408.25 & 10 & 40.83 & 6.93 & 0.0002 & 13.75 & 0.0049 & \\
Quadratic & 510.25 & 14 & 36.45 & 55.13 & $<0.0001$ & 8.25 & 0.4258 & Suggested \\
Cubic & 515.75 & 22 & 23.44 & 37.16 & $<0.0001$ & 1.14 & 0.3296 & \\
\hline
\end{tabular}


Table 4 Designed experiments based on CCD

\begin{tabular}{|c|c|c|c|c|c|c|}
\hline Run & $\mathrm{pH}$ & $\begin{array}{l}\text { Ozone }(\mathrm{mg} / \\
\text { l.min) }\end{array}$ & DC(A) & $\begin{array}{l}\text { Reaction } \\
\text { time(min) }\end{array}$ & $\begin{array}{l}\text { Observed COD } \\
\text { removal }(\%)\end{array}$ & $\begin{array}{l}\text { Predicted COD } \\
\text { removal }(\%)\end{array}$ \\
\hline 1 & 6 & 30 & 56.2 & 125 & 78 & 78.3 \\
\hline 2 & 4.00 & 20.00 & 75.00 & 100.00 & 79 & 78.95 \\
\hline 3 & 6.00 & 30.00 & 56.25 & 25.00 & 67 & 67.3 \\
\hline 4 & 6.00 & 30.00 & 93.75 & 75.00 & 73 & 73.3 \\
\hline 5 & 6.00 & 30.00 & 56.25 & 75.00 & 75 & 74.8 \\
\hline 6 & 10.00 & 30.00 & 56.25 & 75.00 & 71 & 71.5 \\
\hline 7 & 4.00 & 20.00 & 37.50 & 100.00 & 71 & 70.7 \\
\hline 8 & 6.00 & 10.00 & 56.25 & 75.00 & 69 & 69.3 \\
\hline 9 & 8.00 & 40.00 & 37.50 & 100.00 & 70 & 69.7 \\
\hline 10 & 4.00 & 40.00 & 37.50 & 100.00 & 70 & 69.95 \\
\hline 11 & 8.00 & 40.00 & 75.00 & 50.00 & 71 & 70.7 \\
\hline 12 & 6.00 & 30.00 & 56.25 & 75.00 & 75 & 74.8 \\
\hline 13 & 8.00 & 20.00 & 37.50 & 100.00 & 72 & 67.95 \\
\hline 14 & 6.00 & 30.00 & 56.25 & 75.00 & 75 & 74.8 \\
\hline 15 & 4.00 & 40.00 & 75.00 & 100.00 & 78 & 77.7 \\
\hline 16 & 6.00 & 50.00 & 56.25 & 75.00 & 70 & 70.3 \\
\hline 17 & 8.00 & 20.00 & 75.00 & 50.00 & 65 & 64.95 \\
\hline 18 & 6.00 & 30.00 & 18.75 & 75.00 & 63 & 63.3 \\
\hline 19 & 8.00 & 20.00 & 75.00 & 100.00 & 78 & 77.7 \\
\hline 20 & 8.00 & 20.00 & 37.50 & 50.00 & 65 & 64.7 \\
\hline 21 & 4.00 & 20.00 & 75.00 & 50.00 & 69 & 68.7 \\
\hline 22 & 6.00 & 30.00 & 56.25 & 75.00 & 74 & 77.8 \\
\hline 23 & 8.00 & 40.00 & 75.00 & 100.00 & 76 & 75.95 \\
\hline 24 & 4.00 & 20.00 & 37.50 & 50.00 & 67 & 66.95 \\
\hline 25 & 6.00 & 30.00 & 56.25 & 75.00 & 76 & 74.8 \\
\hline 26 & 4.00 & 40.00 & 75.00 & 50.00 & 72 & 71.95 \\
\hline 27 & 6.00 & 30.00 & 56.25 & 75.00 & 74 & 74.83 \\
\hline 28 & 2.00 & 30.00 & 56.25 & 75.00 & 75 & 75.3 \\
\hline 29 & 8.00 & 40.00 & 37.50 & 50.00 & 68 & 6.95 \\
\hline 30 & 4.00 & 40.00 & 37.50 & 50.00 & 69 & 68.7 \\
\hline
\end{tabular}

rate of radicals' production [24]. The results indicated that the efficacy of the process for COD removal was closed in the selected range of $\mathrm{pH}$ value. However, with increasing the $\mathrm{pH}$ value from acidic to alkaline, efficiency was relatively reduced. According to previous studies, in the conventional ozonation process, through increasing the $\mathrm{pH}$ to the alkaline range, the ozone molecule reacts with the hydroxyl ion $\left(\mathrm{OH}^{-}\right)$ and produces $\mathrm{HO}_{2}{ }^{-}$ion (Eq. 13). Further, this ion reacts with the ozone molecule and generates $\mathrm{OH}^{\bullet}$ (Eq. 14).

$\mathrm{O}_{3}+\mathrm{OH}^{-} ? \mathrm{HO}_{2}^{-}+\mathrm{O}_{2}$

$\mathrm{HO}_{2}^{-}+\mathrm{O}_{3} \rightarrow \mathrm{OH}^{\bullet}+\mathrm{O}_{2}^{\bullet-}+\mathrm{O}_{2}$

In the UV-EPP, an affirmative condition for $\mathrm{H}_{2} \mathrm{O}_{2}$ electrogeneration is generated in a slightly acidic solution. While, in alkaline solution, $\mathrm{H}_{2} \mathrm{O}_{2}$ only formed via electro generation and produce oxygen and $\mathrm{H}_{2} \mathrm{O}$ molecule through self- destruction. Furthermore, in the electrochemical production of $\mathrm{H}_{2} \mathrm{O}_{2} / \mathrm{HO}_{2}$, the formation of $\mathrm{HO}_{2}^{-}$is a sub-reaction between the hydroxyl ion and the ozone molecule, which lead to reduction of the ozone in the solution. This sub-reaction decreases reaction rate of ozone with $\mathrm{H}_{2} \mathrm{O}_{2}$ and $\mathrm{HO}_{2}$, resulting in less creation of radical hydroxylation. On the other hand, due to the reduction of ozone and increasing the $\mathrm{HO}_{2}{ }^{-}$amount relative to ozone, $\mathrm{HO}_{2}^{-}$acts as a radical scavenger and competes with the pollutant in radical hydroxyl consumption (Eq. 15).

$\mathrm{HO}_{2}^{-}+\mathrm{OH}^{\bullet} \rightarrow \mathrm{H}_{2} \mathrm{O}^{\bullet}+\mathrm{OH}^{-}$

The most important point of this process is the favorable efficiency of in a wide range of $\mathrm{pH}$ value. Since the industrial wastewater and leachate have a varied $\mathrm{pH}$, so UV-EPP can be used as a promising method to treat the pollutants. In previous 
Table 5 ANOVA of the fitted models for COD removal in UVEPP

\begin{tabular}{|c|c|c|c|c|c|c|}
\hline Source & $\begin{array}{l}\text { Sum of } \\
\text { Squares }\end{array}$ & $\mathrm{df}$ & $\begin{array}{l}\text { Mean } \\
\text { Square }\end{array}$ & $\begin{array}{l}\text { F- } \\
\text { Value }\end{array}$ & $\begin{array}{l}p \text {-value Prob }> \\
\text { F }\end{array}$ & \\
\hline Model & 510.25 & 14 & 36.45 & 55.13 & $<0.0001$ & significant \\
\hline A-pH & 13.50 & 1 & 13.50 & 20.42 & 0.0004 & \\
\hline $\begin{array}{l}\text { B-Ozone } \\
\text { concentration }\end{array}$ & 4.17 & 1 & 4.17 & 6.30 & 0.0240 & \\
\hline C-Applied current & 130.67 & 1 & 130.67 & 197.65 & $<0.0001$ & \\
\hline D-Reaction time & 204.17 & 1 & 204.17 & 308.82 & $<0.0001$ & \\
\hline $\mathrm{AB}$ & 0.25 & 1 & 0.25 & 0.38 & 0.0478 & \\
\hline $\mathrm{BC}$ & 1.00 & 1 & 1.00 & 1.51 & 0.0277 & \\
\hline $\mathrm{BD}$ & 25.00 & 1 & 25.00 & 37.82 & $<0.0001$ & \\
\hline $\mathrm{CD}$ & 25.00 & 1 & 25.00 & 37.82 & $<0.0001$ & \\
\hline $\mathrm{A}^{\wedge} 2$ & 3.86 & 1 & 3.86 & 5.83 & 0.0289 & \\
\hline $\mathrm{B}^{\wedge} 2$ & 42.86 & 1 & 42.86 & 64.83 & $<0.0001$ & \\
\hline $\mathrm{C}^{\wedge} 2$ & 72.43 & 1 & 72.43 & 109.56 & $<0.0001$ & \\
\hline $\mathrm{D}^{\wedge} 2$ & 6.86 & 1 & 6.86 & 10.37 & 0.0057 & \\
\hline Residual & 9.92 & 15 & 0.66 & & & \\
\hline Lack of Fit & 7.08 & 10 & 0.71 & 1.25 & 0.4258 & $\begin{array}{l}\text { Not } \\
\quad \text { significan }\end{array}$ \\
\hline Pure Error & 2.83 & 5 & 0.57 & & & \\
\hline Cor Total & 520.17 & 29 & & & & \\
\hline
\end{tabular}

studies, several researchers reported the effect of $\mathrm{pH}$ value on the efficiency of Electroproxone processes. Yujue Wang et al. $[10]$ reported the EP process with similar result in 3 and $7 \mathrm{pH}$ values in the degradation of Orange II dye. Gang Yu et al. [25] also reported the similar result of EP process in 3 and $7 \mathrm{pH}$ values in the degradation of ibuprofen. furthur in $\mathrm{pH}$ equal to 10 , the efficiency of EP process was decreased.

According to the mass transfer theory, enhancing the amount of ozone intake into the reactor increases the concentration of soluble ozone in the aqueous. The ozone gas has a direct and indirect role in UV-EPP, i: direct oxidation of organic pollutant via ozone gas, ii: decomposition of ozone molecule and reaction with $\mathrm{H}_{2} \mathrm{O}_{2}$ to produce $\mathrm{OH}^{\bullet}$ as a nonselective oxidant. The efficiency of the process can be developed by increasing the ozone input to the reactor up to a certain concentration of ozone molecules. However, due to the weak solubility of ozone in solution, transfering from the gas phase to the liquid phase is limited. In other words, increasing inlet concentration of ozone does not lead to more immigration of ozone gas to the aqueous phase [26]. The
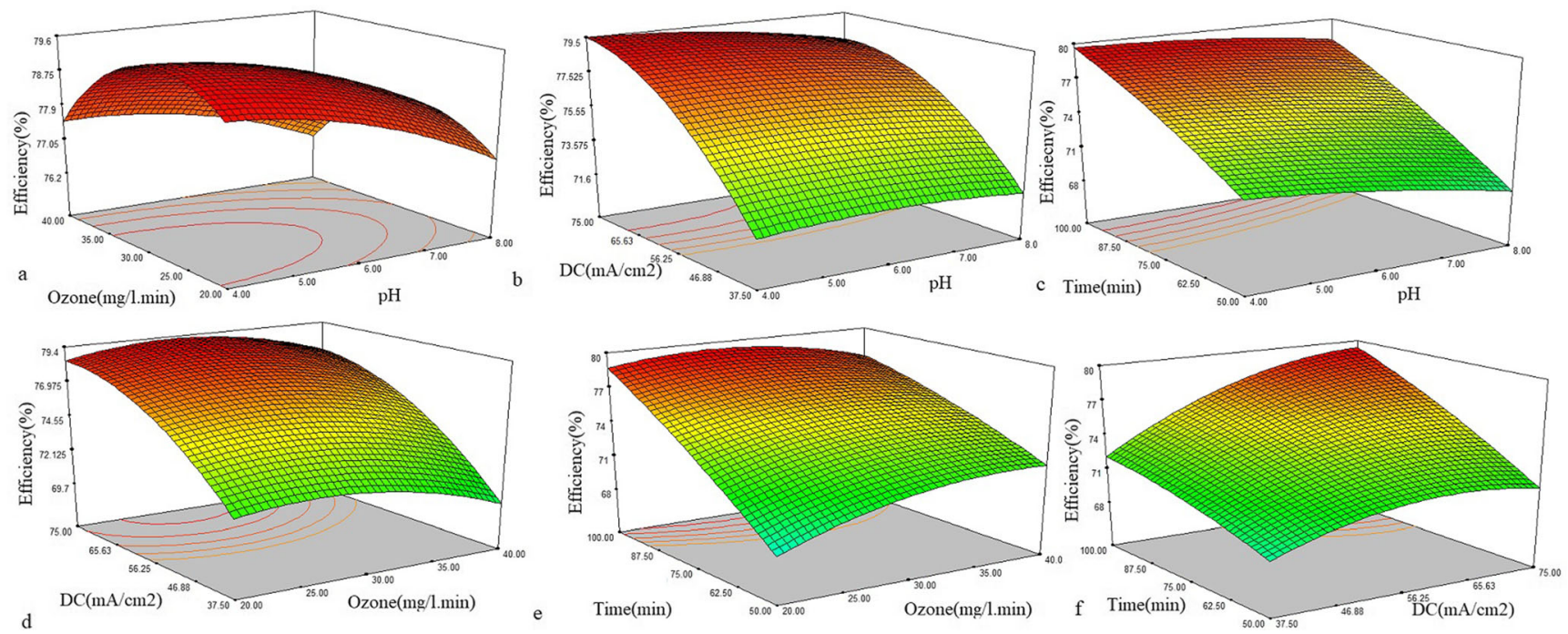

Fig. 3 Response surface plots 
Wang et al. [27] results indicated that the efficiency is improved via increasing ozone concentration in MB removal by EP and the highest ozone concentration shows highest efficiency. The report by Zhaoxin Li et al. [28] showed that via increasing ozone concentration in the degradation of refractory organic pollutants in landfill leachate, the efficiency of the process was improved and high performance earns in $154 \mathrm{mg} / \mathrm{l} \mathrm{O}_{3}$. In Kermani et al. [29] study reported that the high efficiency of EPP was obtained at slightly acidic $\mathrm{pH}$.

According to Fig. $3 \mathrm{~b}$, the $\mathrm{pH}$ value and the applied direct current were independent variables and other factors were considered constant in the central point values $\left(\mathrm{O}_{3}=30 \mathrm{mg} /\right.$ 1.min, $\mathrm{RT}=75 \mathrm{~min}$ ). Based on results, the direct current parameter has a significant effect on UV-EPP efficiency and its high value lead to improved efficiency in COD removal. This is due to the fact that increasing applied electrical current enhances the electro-production of $\mathrm{H}_{2} \mathrm{O}_{2}$ at the graphenebased cathode. As a result, hydroxyl radicals are produced more than the amount produces in the reaction between ozone and $\mathrm{H}_{2} \mathrm{O}_{2}$. Furthermore, high applied current causes more cathodic activation and anodic direct oxidation of ozone molecules. However, after the optimum value of applied current, the efficiency of the process became stable. For this subject, two reasons are involved: (i) the ability to react between $\mathrm{H}_{2} \mathrm{O}_{2}$ and ozone molecules is limited because certain amount of ozone gas dissolves in the solution. (ii) through increasing the applied current, interfaces reaction was accrued in solution, in which caused disturbing the $\mathrm{H}_{2} \mathrm{O}_{2}$ electro-generation and the production of a water molecule happened via oxygen reduction. Also, higher current of $\mathrm{H}_{2} \mathrm{O}_{2}$ was oxidized in anode part (Eq. 16).

$\mathrm{H}_{2} \mathrm{O}_{2} ? \mathrm{O}_{2}+2 \mathrm{H}^{+}+2 e^{-}$

In other hands, the low dissolution of ozone molecules in the solution caused a dramatic decreasing in the rate of $\mathrm{H}_{2} \mathrm{O}_{2}$ converting to the $\mathrm{OH}^{\bullet}$ and $\mathrm{H}_{2} \mathrm{O}_{2}$ remain in the solution. Since $\mathrm{H}_{2} \mathrm{O}_{2}$ is not a powerful oxidant, the process efficiency is reduced [4]. Qiu et al. [30] investigated the p-nitro phenol mineralization through a combined process. The result indicated that an optimum electrical current for the removal of pollutants is $100 \mathrm{~mA}$. In report by Ahmadi et al. [31], photoelectro-peroxone/ZVI process was used for the degradation of organic pollutants. The result showed that $300 \mathrm{~mA}$ applied current has the highest efficiency among other values $(0,100,300$ and $400 \mathrm{~mA}$ applied current). Also in Bernal-Martinez at al [32], examined the effect of synergy of EC and ozonation processes in industrial wastewater treatment. In the given study, $10-40 \mathrm{~mA}$ $\mathrm{cm}^{-2}$ current density and $5 \mathrm{mg} \mathrm{L}^{-1}$ ozone concentration were applied. The maximum of COD removal efficiency (84\%) was achieved in current densities of $20 \mathrm{~mA} \mathrm{~cm}{ }^{-2}$ and $\mathrm{pH}$ of 7 .
According to Fig. 3c, $\mathrm{pH}$ value and reaction time were independent parameters and other variables were considered constant in the central point values (DC $=65 / 25 \mathrm{~mA} / \mathrm{cm}^{2}$, $\mathrm{O}_{3}=30 \mathrm{mg} / \mathrm{l} \cdot \mathrm{min}$ ). Based on results, the reaction time as a variable has a significant effect on UV-EPP efficiency and longer reaction time caused improved COD removal. Also $\mathrm{pH}$ has the same effect in the selected range as shown in Fig. 3a. Obviously, by increasing the concentration of pollutants in the solution, more oxidants such as $\mathrm{OH}^{\bullet}$, and Ozone molecules are consumed. Therefore, higher reaction time is necessary for mineralization because other parameters such as photolysis, electrolysis, ozonation and $\mathrm{OH}^{\bullet}$ are instant values. In Mina Gharchi et al. [33], repoted that significat removal of COD obtained in $3 \mathrm{~h}$ in optimum condition.

After optimizing the process and determining the proposed optimal conditions by the model, $\mathrm{pH}=5.62$, ozone concentration $=29.11 \mathrm{mg} / 1 . \mathrm{min}$, current density $=74.71 \mathrm{~mA} / \mathrm{cm}^{2}$, and reaction time $=98.63$ was proposed by software. According to the predicate point, the efficiency of COD removal in optimum condition was 84.83 and 83 percent as a theatrical and experimental removal via UV-EPP.

\section{$\mathrm{H}_{2} \mathrm{O}_{2}$, and $\mathrm{OH}^{\bullet}$ production during optimum condition}

Through using graphene as a cathode and sparged $\mathrm{O}_{2}$ gas to the reactor, the $\mathrm{H}_{2} \mathrm{O}_{2}$ concentration increased linearly with electrolysis time and reached to $1.95 \mathrm{gr}(55 / 33 \mathrm{mM})$ under $74.71 \mathrm{~mA} / \mathrm{cm}^{2}$ of current density after 120 min electrolysis (Fig. 4).

These results indicated that the ozone quickly reacted in situ with the electrogenerated $\mathrm{H}_{2} \mathrm{O}_{2}$ to produce $\mathrm{OH}^{\bullet}$ (Fig. 4), that was successively taken by TA to generate HTA. Moreover, owing to the particularly $\mathrm{OH}^{\bullet}$ short life, this radical cannot collect in a solution. On the other hand, the continuous increase of HTA concentration as electrolysis point out the constant generation of $\mathrm{OH}^{\bullet}$ in this system. Bo Yang et al. [10] investigated $\mathrm{H}_{2} \mathrm{O}_{2}, \mathrm{O}_{3}$, and $\mathrm{OH}^{\bullet}$ generation during electrolysis process. In this study, $21.2 \mathrm{mM} \mathrm{H}_{2} \mathrm{O}_{2}$ was generated, under $30 \mathrm{~mA} / \mathrm{cm}^{2}$ of current density after $30 \mathrm{~min}$ of electrolysis. In another study by Wang at el.[34], in $60 \mathrm{~min}$ and $500 \mathrm{~mA}$ applied current, $800 \mathrm{mg} / \mathrm{H} \mathrm{H}_{2} \mathrm{O}_{2}$ was generated.

\section{Survey of synergist effect of ozonation, electrolysis and photolysis}

Investigating the effect of every mechanism that involved in the UV-EPP process can well determine the relationship between the mechanisms. In this study, the main mechanism affecting on the UV-EPP are considered to be (1) the ozonation process in which ozone acts as a direct oxidizing agent and the radical hydroxyl activation factor, (2) the electrolysis process as anodic oxidation leading to production of hydrogen 
Fig. $4 \mathrm{H}_{2} \mathrm{O}_{2}$ and $\mathrm{OH}^{\bullet}$ production in optimum condition

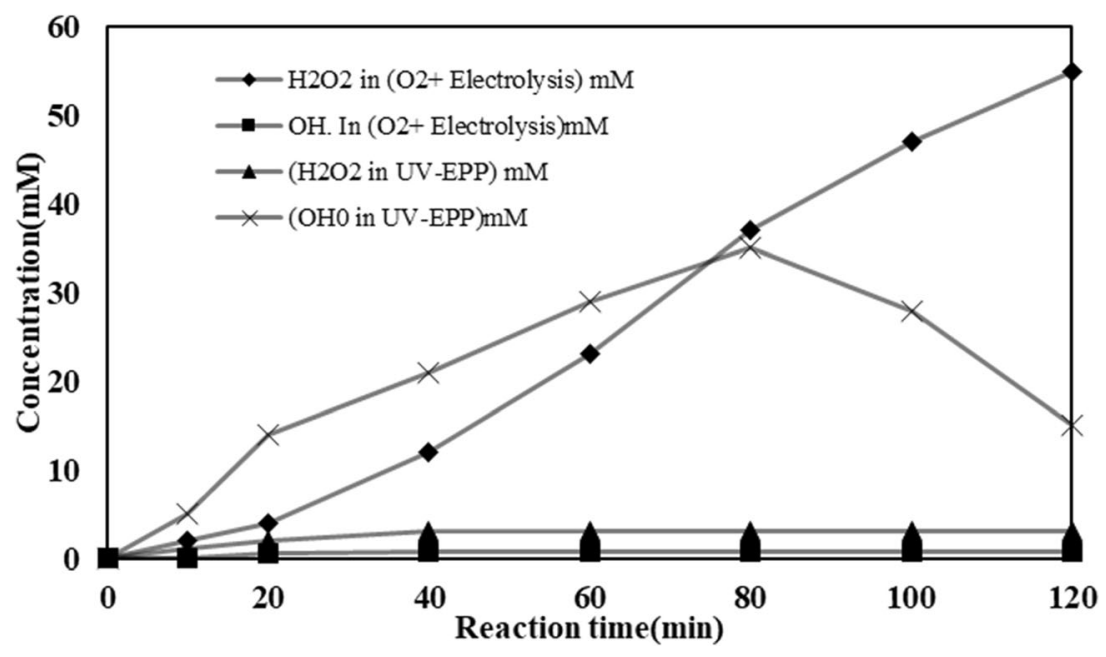

peroxide and radical hydroxyl and (3) photolysis. The results showed that each of the mechanism separately has a lower efficiency than their combination (Fig. 5).

According to experimental results, photolysis, electrolysis and ozonation process separately has 7,21 and 26 percent of COD removal, respectively. The study by Mizutani et al. [19] found that the efficacy of the simple ozonation process and the electrolysis process separately in the removal of 1-4 dioxin as an indicator of organic compounds is much lower than when two processes are merged together.

\section{Energy consumption in UV-EPP}

SER for COD removal in photolysis, electrolysis, ozonation and UV-EPP are presented in Table 6.

The report by Ahmadi et al. [31] investigated the specific consumption of energy in electrolysis, ozonation and Eperoxone process. In this research, as a merged procedure, the E-peroxone method not only considerably improved TOC removal but also significantly enhanced the energy efficiency for TOC elimination in comparison with the two separate procedures. In another report by Shen et al. [35] the energy efficiency was investigated. In this study, after 45 min of treatment, the $\mathrm{UV} / \mathrm{O}_{3}, \mathrm{EP}$, and PEP procedures eliminated $70 \%, 37 \%$, and $98 \%$ of TOC from 1,4-dioxane solutions with $\mathrm{SEC}$ of $0.38 \mathrm{kWh} / \mathrm{g}$ TOC removed, $0.22 \mathrm{kWh} / \mathrm{g}$ TOC removed, and $0.30 \mathrm{kWh} / \mathrm{g}$ TOC removed, respectively

\section{Kinetic investigation}

Kinetic investigation demonstrated that COD removal follows pseudo-first-order kinetics in UV-EPP. Particularly, the obvious COD removal rate constants (kUV-EPP) in the UV-EPP is meaningfully greater than the linear addition of the separate rates of resultant ozonation, photolysis, and electrolysis procedures. Kinetics can be reordered easily to an apparent first
Fig. 5 synergist effect of parameters on UV-EPP

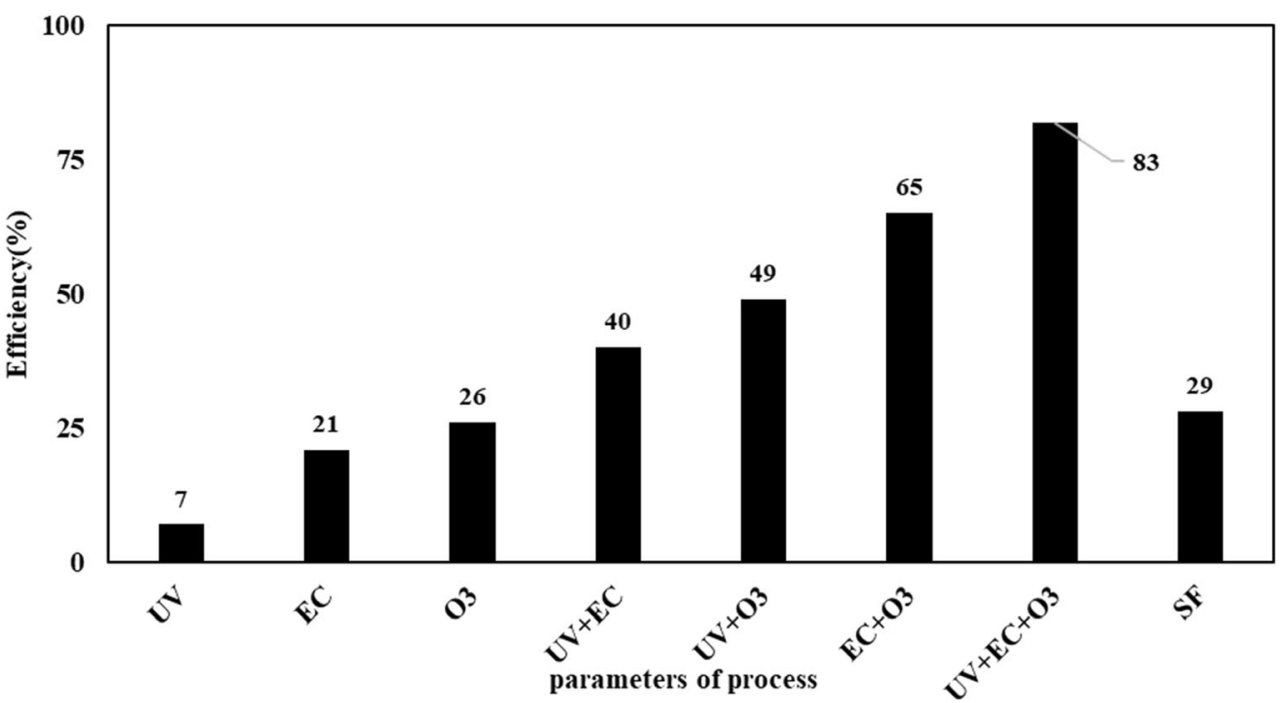


Table 6 Energy consumption in UV-EPP

\begin{tabular}{|c|c|c|c|}
\hline & Process and mechanism & Condition & Energy requirment $(\mathrm{kWh})$ \\
\hline \multirow[t]{2}{*}{1} & Photolysis & Time $=100 \mathrm{~min}$ & 0.09 \\
\hline & Electrolysis & $\begin{array}{l}\mathrm{CO} \text { and } \mathrm{Ct}=9400 \text { and } 8742 \mathrm{mg} / \mathrm{l} \text { respectively } \\
\text { Time }=100 \mathrm{~min}\end{array}$ & 0.5 \\
\hline 2 & & $\begin{array}{l}C 0 \text { and } C t=9400 \text { and } 7426 \mathrm{mg} / \mathrm{l} \text { respectively } \\
A=1 \mathrm{~A}, \mathrm{~V}=10 \mathrm{~V}\end{array}$ & \\
\hline \multirow[t]{2}{*}{3} & Ozonation & Time $=100 \mathrm{~min}$ & 0.49 \\
\hline & & $\begin{array}{l}C 0 \text { and } C t=9400 \text { and } 6956 \mathrm{mg} / \mathrm{l} \text { respectively } \\
r=10 \mathrm{kWh} / \mathrm{kg} \mathrm{o} 3=10 \\
\text { ozone concentration }=29.11 \mathrm{mg} / \mathrm{l} . \mathrm{min}\end{array}$ & \\
\hline \multirow[t]{5}{*}{4} & UV-EPP & Time $=100 \mathrm{~min}$ & 1.5 \\
\hline & & $C 0$ and $C t=9400$ and $1692 \mathrm{mg} / \mathrm{l}$ respectively & \\
\hline & & $A=1 A, V=10 \mathrm{~V}$ & \\
\hline & & $r=10 \mathrm{kWh} / \mathrm{kg} \mathrm{o3}=10$ & \\
\hline & & ozone concentration $=29.11 \mathrm{mg} / \mathrm{l} \cdot \mathrm{min}$ & \\
\hline
\end{tabular}

order equation (Eq. 17):

$\ln \left(\frac{\mathrm{C}_{0}}{\mathrm{C}}\right)=\mathrm{kt}$

Where $\mathrm{k}_{\mathrm{UV}-\mathrm{EPP}}$ shows the first order rate constant of the COD removal. A plot of $\ln \left(\mathrm{C}_{\mathrm{o}} / \mathrm{C}\right)$ versus time shows linear behavior, the slope of which upon linear regression equals the $\mathrm{k}_{\mathrm{UV}-\mathrm{EPP}}$. Usually, first-order kinetics are suitable for different investigations which practically well close-fitting by this kinetic model. Figure 6 represents the first order kinetics elimination of COD.

As demonstrated in Fig. 6, the removal of COD by UVEPP was significant. Effectively, COD elimination due to the production of $\mathrm{OH}^{\bullet}$.Also, Pearson coefficient and chisquare $\left({ }^{2}\right)$ value were calculated and their values were set to 20 and 0.02 , respectively. A report by Dominguez et al.
[36] investigated the lindane degradation by the electrooxidation process. In this research, the kinetics of degradation followed by a pseudo-first order reaction for lindane oxidation.

\section{Conclusion}

Here in, we investigated the performance of COD removal via UV-EPP as a hybrid advance oxidation process. The results demonstrated that electrochemical activation of $\mathrm{H}_{2} \mathrm{O}_{2}$ significantly enhanced the removal of COD. The experimental data also confirm that UV-EPP as a hybrid advance oxidation procedure has a developed effectiveness than ozonation, electrolysis and photolysis, separately. In this case, the electrochemically and photocatalytic activated $\mathrm{H}_{2} \mathrm{O}_{2}$ increased the formation of $\mathrm{OH}^{\bullet}$. Table 7
Fig. 6 The first order kinetics of COD removal by UV-EPP

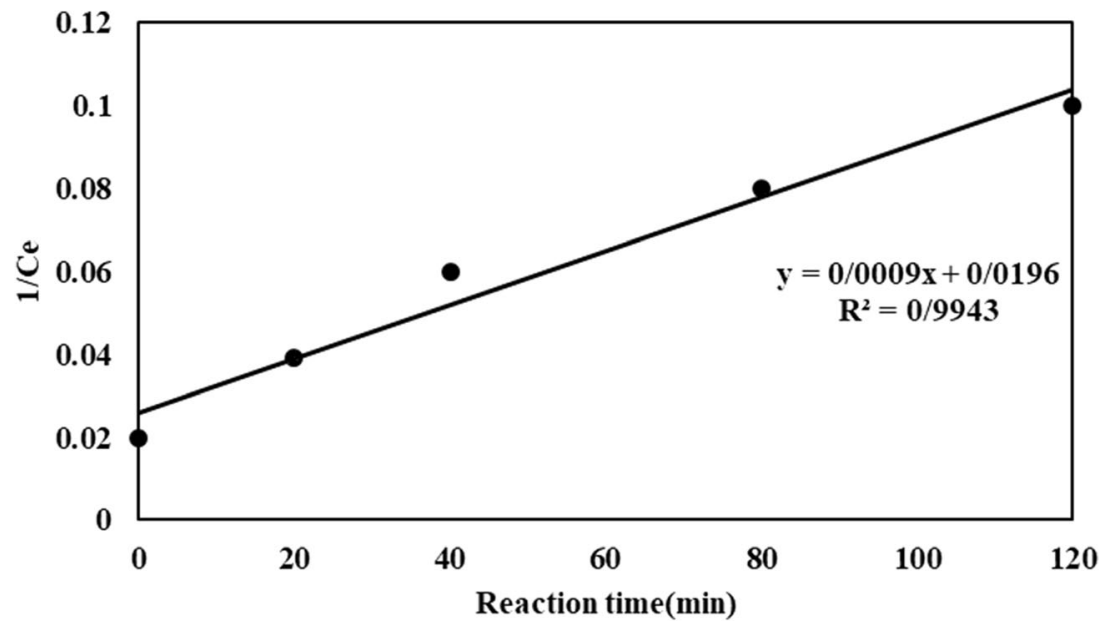


Table 7 Summary of the process for leachate treatment

\begin{tabular}{|c|c|c|c|}
\hline Title & Operating conditions & Results and comments & $\begin{array}{l}\text { References } \\
\text { and } \\
\text { Authors }\end{array}$ \\
\hline Heterogeneous Fenton \& electro-Fenton procedures & $\begin{array}{l}\text { Iron-manganese binary oxide loaded } \\
\text { zeolite (IMZ) was applied as a } \\
\text { catalyst for producing } \mathrm{OH}^{\bullet} \text { in the } \\
\text { solution. }\end{array}$ & $\begin{array}{l}\text { 88.6\% COD from landfill leachate at } \\
\text { the optimum situations. } \\
\text { After Fenton treatment, } \\
\text { biodegradability of landfill } \\
\text { leachate was enhanced } \\
\text { considerably from } 0.03 \text { to } 0.52\end{array}$ & {$[37]$} \\
\hline $\begin{array}{l}\text { Electrochemical/peroxydisulfate } / \mathrm{Fe}^{3+} \text { treatment \& } \\
\text { ultrafiltration }\end{array}$ & $\begin{array}{l}\text { The reactions were done in an } \\
\text { electrolytic vessel with separated } \\
\text { anode and cathode chambers and } \\
\text { has been divided through a } \\
\text { protonexchange membrane. }\end{array}$ & $\begin{array}{l}\text { Anode } / \mathrm{PS} / \mathrm{Fe}^{3+} \text { Cathode } / \mathrm{PS} / \mathrm{Fe}^{3+} \\
\text { procedure has the greatest impact } \\
\text { on the organics destruction. }\end{array}$ & {$[38]$} \\
\hline $\begin{array}{l}\text { Integrated } \\
\text { Electro-Oxidation/Electro-Coagulation/Electro-Reduct- } \\
\text { ion procedure }\end{array}$ & $\begin{array}{l}\text { The influence of Factors such as } \\
\text { leachate characteristics and } \\
\text { procedure conditions on the } \\
\text { efficiency of EO/EC/ER procedure } \\
\text { was studied }\end{array}$ & $\begin{array}{l}\text { simultaneous removal of } \\
\text { carbonaceous and nitrogenous } \\
\text { pollutants was attained in optimum } \\
\text { conditions }\end{array}$ & [39] \\
\hline Ozonation \& supercritical water oxidation procedures & $\begin{array}{l}\text { Ozonation was done at different } \\
\text { reaction times }(30-120 \mathrm{~min}) \text {. } \\
\text { ScWO was studied at } 600{ }^{\circ} \mathrm{C} \text {, } \\
23 \mathrm{MPa} \text {, and spatial time }(\tau) \text { from } \\
29 \text { to } 52 \mathrm{~s} \text {. }\end{array}$ & $\begin{array}{l}\text { A mixture of ozonation ( } 30 \mathrm{~min}) \text { and } \\
\text { supercritical water oxidation } \\
\text { procedure }\left(\mathrm{O}_{3}-30 \text { '/ScWO) was the }\right. \\
\text { best method for the leachate } \\
\text { degradation. These conditions } \\
\text { allowed the great value removal of } \\
\text { apparent and true color }(92 \% \text { and } \\
97 \% \text {, respectively), biochemical } \\
\text { oxygen demand (BOD5,20) } \\
\text { (95\%), chemical oxygen demand } \\
\text { (COD) }(92 \%) \text {, total organic carbon } \\
\text { (TOC) }(79 \%) \text {, nitrite }(78 \%) \text {, nitrate } \\
\text { ( } 84 \%) \text {, total }(96 \%) \text {, dissolved } \\
\text { (96\%) and suspended }(94 \%) \\
\text { solids. }\end{array}$ & {$[40]$} \\
\hline $\begin{array}{l}\text { Photo-Electroproxone Optimization and modeling in } \\
\text { Leachtae Treatment }\end{array}$ & $\begin{array}{l}\mathrm{pH}(4-8), \mathrm{DC}(56 / 25-75 \mathrm{~mA} / \mathrm{cm} 2), \\
\text { ozone } \\
\text { concentration(20-40 mg/l.min), } \\
\text { Time }(50-100 \mathrm{~min}) \text {,designed via } \\
\text { CCD }\end{array}$ & $\begin{array}{l}\mathrm{pH}=5.6, \text { ozone concentration }= \\
29 / 1 \mathrm{mg} / \mathrm{l} . \mathrm{min} \text {, direct current }= \\
74 / 7 \mathrm{~mA} / \mathrm{cm}^{2} \text {, and reaction time }= \\
98 / 63 \mathrm{~min} \text { was determined. } \\
\text { According to predicate point, the } \\
\text { percentage of removal in optimum } \\
\text { condition was } 84 / 83 \text { and } 83 \text { as a } \\
\text { theatrical and experimental COD } \\
\text { removal percentage via UV-EPP. }\end{array}$ & This study \\
\hline
\end{tabular}

represent the summery of other reports on leachate treatment.

- The optimum condition for UV-EPP is $\mathrm{pH}=5 / 62, \mathrm{DC}=$ $74 / 71 \mathrm{~mA} / \mathrm{cm}^{2}$, ozone gas concentration $=29.11 \mathrm{mg} / 1 . \mathrm{min}$ and reaction time $=98 / 63 \mathrm{~min} .83$ percent of initial leachate COD was removed via UV-EPP in this condition.

- The reaction followed first-order kinetics model.

- The ozonation, electrolysis, and photolysis mechanism have lower efficiency in COD removal, separately. UV-
EPP as a hybrid advance oxidation process have a synergist effect and increase COD removal in leachate.

- 29 percent synergist effect was obtained through applying hybridization.

- In the optimum condition of UV-EPP, 55/33 mM $\mathrm{H}_{2} \mathrm{O}_{2}$ was generated in an electrochemical process.

- The optimum $1.5 \mathrm{~kW} / \mathrm{h} . \mathrm{kg}$ COD electrical energy was required for leachate treatment.

Acknowledgements We would like to thank Student Research Committe of Iran University of Medical Sciences for financial support of this research project (GN: 98-1-15-14904). 
Open Access This article is licensed under a Creative Commons Attribution 4.0 International License, which permits use, sharing, adaptation, distribution and reproduction in any medium or format, as long as you give appropriate credit to the original author(s) and the source, provide a link to the Creative Commons licence, and indicate if changes were made. The images or other third party material in this article are included in the article's Creative Commons licence, unless indicated otherwise in a credit line to the material. If material is not included in the article's Creative Commons licence and your intended use is not permitted by statutory regulation or exceeds the permitted use, you will need to obtain permission directly from the copyright holder. To view a copy of this licence, visit http://creativecommons.org/licenses/by/4.0/.

\section{References}

1. Hassan M, Zhao Y, Xie B. Employing TiO2 photocatalysis to deal with landfill leachate: current status and development. Chem Eng J. 2016;285:264-75.

2. Yang Q, Zhong Y, Zhong H, Li X, Du W, Li X, et al. A novel pretreatment process of mature landfill leachate with ultrasonic activated persulfate: Optimization using integrated Taguchi method and response surface methodology. Process Saf Environ Prot. 2015;98:268-75.

3. Jiang F, Qiu B, Sun D. Advanced degradation of refractory pollutants in incineration leachate by UV/Peroxymonosulfate. Chem Eng J. 2018;349:338-46.

4. Moazzen M, Khaneghah AM, Shariatifar N, Ahmadloo M, Eş I, Baghani AN, et al. Multi-walled carbon nanotubes modified with iron oxide and silver nanoparticles (MWCNT-Fe3O4/Ag) as a novel adsorbent for determining PAEs in carbonated soft drinks using magnetic SPE-GC/MS method. Arab J Chem. 2019;12(4):476-88.

5. Frangos P, Wang H, Shen W, Yu G, Deng S, Huang J, et al. A novel photoelectro-peroxone process for the degradation and mineralization of substituted benzenes in water. Chem Eng J. 2016;286:23948.

6. Naghan DJ, Azari A, Mirzaei N, Velayati A, Tapouk FA, Adabi S, et al. Parameters effecting on photocatalytic degradation of the phenol from aqueous solutions in the presence of $\mathrm{ZnO}$ nanocatalyst under irradiation of UV-C light. Bul Chem Commun. 2015;47(Specia):14-8.

7. Wang H, Zhan J, Yao W, Wang B, Deng S, Huang J, et al. Comparison of pharmaceutical abatement in various water matrices by conventional ozonation, peroxone $(\mathrm{O} 3 / \mathrm{H} 2 \mathrm{O} 2)$, and an electroperoxone process. Water Res. 2018;130:127-38.

8. Esrafili A, Rezaei Kalantary R, Azari A, Ahmadi E, Gholami M. Removal of diethyl phthalate from aqueous solution using persulfate-based (UV/Na2S2O8/Fe2+) advanced oxidation process. J Mazandaran Univ Med Sci. 2016;25(132):122-35.

9. Li Y, Shen W, Fu S, Yang H, Yu G, Wang Y. Inhibition of bromate formation during drinking water treatment by adapting ozonation to electro-peroxone process. Chem Eng J. 2015;264:322-8.

10. Yang B, Deng J, Yu G, Deng S, Li J, Zhu C, et al. Effective degradation of carbamazepine using a novel electro-peroxone process involving simultaneous electrochemical generation of ozone and hydrogen peroxide. Electrochem Commun. 2018;86:26-9.

11. Jaafarzadeh N, Barzegar G, Ghanbari F. Photo assisted electroperoxone to degrade 2, 4-D herbicide: the effects of supporting electrolytes and determining mechanism. Process Saf Environ Prot. 2017;111:520-8.

12. Yegane Badi M, Vosoughi M, Sadeghi H, Mokhtari SA, Mehralipour J. Ultrasonic-assisted $\mathrm{H} 2 \mathrm{O} 2 / \mathrm{TiO} 2$ process in catechol degradation: kinetic, synergistic and optimisation via response surface methodology. Int J Environ Anal Chem. 2020. https://doi.org/ $10.1080 / 03067319.2020 .1726335$
13. Monforte AR, Oliveira C, Martins SI, Ferreira ACS. Response surface methodology: A tool to minimize aldehydes formation and oxygen consumption in wine model system. Food Chem. 2019;283:559-65.

14. Salari M, Dehghani MH, Azari A, Motevalli MD, Shabanloo A, Ali I. High performance removal of phenol from aqueous solution by magnetic chitosan based on response surface methodology and genetic algorithm. J Mol Liq. 2019;285:146-57.

15. Azari A, Noorisepehr M, Dehghanifard E, Karimyan K, Hashemi SY, Kalhori EM, et al. Experimental design, modeling and mechanism of cationic dyes biosorption on to magnetic chitosanlutaraldehyde composite. Int J Biol Macromol. 2019;131:633-45.

16. Wang H, Shen Y, Lou Z, Zhu N, Yuan H, Liu C. Hydroxyl radicals and reactive chlorine species generation via E+-ozonation process and their contribution for concentrated leachate disposal. Chem Eng J. 2019;360:721-7.

17. Ma C, Yuan P, Jia S, Liu Y, Zhang X, Hou S, et al. Catalytic microozonation by Fe3O4 nanoparticles@ cow-dung ash for advanced treatment of biologically pre-treated leachate. Waste Manag. 2019;83:23-32.

18. Association APH, Association AWW. Standard methods for the examination of water and wastewater: American public health association; 1989

19. Wang H, Bakheet B, Yuan S, Li X, Yu G, Murayama S, et al. Kinetics and energy efficiency for the degradation of 1, 4-dioxane by electro-peroxone process. J Hazard Mater. 2015;294:90-8.

20. Cortez S, Teixeira P, Oliveira R, Mota M. Ozonation as polishing treatment of mature landfill leachate. J Hazard Mater. 2010;182(13):730-4.

21. Gonzalez DH, Kuang XM, Scott JA, Rocha GO, Paulson SE. Terephthalate probe for hydroxyl radicals: yield of 2hydroxyterephthalic acid and transition metal interference. Anal Lett. 2018;51(15):2488-97.

22. Anderson VL, McLean RA. Design of experiments: a realistic approach. Abingdon: Routledge; 2018.

23. Esfe MH, Firouzi M, Rostamian H, Afrand M. Prediction and optimization of thermophysical properties of stabilized A12O3/ antifreeze nanofluids using response surface methodology. J Mol Liq. 2018;261:14-20.

24. Qu C, Lu S, Liang D, Chen S, Xiang Y, Zhang S. Simultaneous electro-oxidation and in situ electro-peroxone process for the degradation of refractory organics in wastewater. J Hazard Mater. 2019;364:468-74.

25. Li X, Wang Y, Yuan S, Li Z, Wang B, Huang J, et al. Degradation of the anti-inflammatory drug ibuprofen by electro-peroxone process. Water Res. 2014;63:81-93.

26. Ayoubi-Feiz B, Mashhadizadeh MH, Sheydaei M. Degradation of diazinon by new hybrid nanocomposites N-TiO2/Graphene/Au and $\mathrm{N}-\mathrm{TiO} 2 /$ Graphene/Ag using visible light photo-electro catalysis and photo-electro catalytic ozonation: Optimization and comparative study by Taguchi method. Sep Purif Technol. 2019;211:704 14.

27. Yuan S, Li Z, Wang Y. Effective degradation of methylene blue by a novel electrochemically driven process. Electrochem Commun. 2013;29:48-51.

28. Li Z, Yuan S, Qiu C, Wang Y, Pan X, Wang J, et al. Effective degradation of refractory organic pollutants in landfill leachate by electro-peroxone treatment. Electrochim Acta. 2013;102:174-82.

29. Kermani M, Mehralipour J, Kakavandi B. Photo-assisted electroperoxone of 2, 4-dichlorophenoxy acetic acid herbicide: Kinetic, synergistic and optimization by response surface methodology. J Water Process Eng. 2019;32:100971.

30. Qiu C, Yuan S, Li X, Wang H, Bakheet B, Komarneni S, et al. Investigation of the synergistic effects for p-nitrophenol mineralization by a combined process of ozonation and electrolysis using a boron-doped diamond anode. J Hazard Mater. 2014;280:644-53. 
31. Ahmadi M, Ghanbari F. Degradation of organic pollutants by photoelectro-peroxone/ZVI process: Synergistic, kinetic and feasibility studies. J Environ Manag. 2018;228:32-9.

32. Barrera Díaz CE, González-Rivas N. The use of $\mathrm{Al}, \mathrm{Cu}$, and $\mathrm{Fe}$ in an integrated electrocoagulation-ozonation process. J Chem. 2015;2015:1-6.

33. Gharchi M, Rezaee A. Electrocatalytic ozonation process supplemented by EDTA-Fe complex for improving the mature landfill leachate treatment. Chemosphere. 2020;263:127858.

34. Wang H, Yuan S, Zhan J, Wang Y, Yu G, Deng S, et al. Mechanisms of enhanced total organic carbon elimination from oxalic acid solutions by electro-peroxone process. Water Res. 2015;80:20-9.

35. Shen W, Wang Y, Zhan J, Wang B, Huang J, Deng S, et al. Kinetics and operational parameters for 1, 4-dioxane degradation by the photoelectro-peroxone process. Chem Eng J. 2017;310:249-58.

36. Dominguez CM, Oturan N, Romero A, Santos A, Oturan MA. Lindane degradation by electrooxidation process: effect of electrode materials on oxidation and mineralization kinetics. Water Res. 2018;135:220-30.
37. Sruthi T, Gandhimathi R, Ramesh S, Nidheesh P. Stabilized landfill leachate treatment using heterogeneous Fenton and electro-Fenton processes. Chemosphere. 2018;210:38-43.

38. Cui Y-H, Xue W-J, Yang S-Q, Tu J-L, Guo X-L, Liu Z-Q. Electrochemical/peroxydisulfate/Fe3 + treatment of landfill leachate nanofiltration concentrate after ultrafiltration. Chem Eng J. 2018;353:208-17.

39. Ding J, Wei L, Huang H, Zhao Q, Hou W, Kabutey FT, et al. Tertiary treatment of landfill leachate by an integrated electro-oxidation/electro-coagulation/electro-reduction process: Performance and mechanism. J Hazard Mater. 2018;351:90-7.

40. Scandelai APJ, Cardozo Filho L, Martins DCC, de Souza Freitas TKF, Garcia JC, Tavares CRG. Combined processes of ozonation and supercritical water oxidation for landfill leachate degradation. Waste Manag. 2018;77:466-76.

Publisher's Note Springer Nature remains neutral with regard to jurisdictional claims in published maps and institutional affiliations. 